\title{
FRANCUSKO-POLSKIE ŻYCIE EDWARDA ALEKSANDRA POŻERSKIEGO
}

Józef Ekielski ${ }^{1}$ - prawnik, długoletni pracownik galicyjskiego Wydziału Krajowego - w spisanych u kresu życia wspomnieniach sporo uwagi poświęcił fundacji ustanowionej przez filantropkę Pelagię Russanowską ${ }^{2}$. Podstawowym jej celem było udzielanie dożywotniego wsparcia weteranom walk o niepodległość Ojczyzny. Wśród jej beneficjentów wymieniony został m.in. Edward Pożerski (18291908) - członek wileńskiej organizacji powstańczej ${ }^{3}$. W 1846 r. $^{4}$,z ławki szkolnej w Wilnie zesłany do Orenburga i wcielony tam do wojska, został ułaskawiony

Dr Dorota Pietrzkiewicz - Katedra Książki i Historii Mediów na Wydziale Dziennikarstwa, Informacji i Bibliologii Uniwersytetu Warszawskiego; e-mail: d.pietrzkiewicz@uw.edu.pl. ORCID: https://orcid.org/0000-0003-3870-5308.

1 Po klęsce powstania wraz z rodzicami i siostrą przebywał na emigracji w Paryżu. Po powrocie na ziemie polskie w 1848 r. ukończył gimnazjum św. Anny w Krakowie, a następnie studnia prawnicze. Początkowo pracował w Namiestnictwie, później przeszedł do Wydziału Krajowego, gdzie był m.in. referentem Fundacji Pelagii Russanowskiej. J. Sokulski, Ekielski Józef, w: Polski Słownik Biograficzny [dalej: PSB], t. VI, Kraków 1948, s. 220-221.

${ }_{2}$ Urodziła się w 1792 r. w rodzinie ziemiańskiej; otrzymała staranne i patriotyczne wychowanie (jako dziecko zapisana została do tercjarek dominikańskich); aktywnie angażowała się w działalność dobroczynną. Była m.in. jedną z założycielek pierwszej ochronki dla dzieci w Krakowie (1846), należała m.in. do Arcybractwa Miłosierdzia, Towarzystwa Dobroczynności, Stowarzyszenia Pań Miłosierdzia św. Wincentego a Paulo. Cały zasobny swój majątek zapisała na cele charytatywne. Zmarła w 1863 r. w Krakowie; pochowana została w grobowców Dominikanów na cmentarzu Rakowickim. Zob. J. EKIELSKI, Fundacja Pelagji Russanowskiej. Urywek z pamiętnika Józefa Ekielskiego dlugoletniego referenta wydzialu krajowego b. Królestwa Galicji i Lodomerji, Miejsce Piastowe: Wydawnictwo Tow. Św. Michała Arch. 1931, [s. 1-2]; U. Perkowska, Russanowska Pelagia, w: PSB, t. XXXIII/1, z. 136, Wrocław 1991, s. 145-146; Nieznane listy dotyczace Fundacji Pelagii Russanowskiej z Biblioteki Polskiej w Paryżu, oprac. P. Bilińśki, T. Skrzyński, „Wrocławskie Studia Wschodnie” 13(2009), s. 143-153.

${ }^{3}$ Urodził się w Janowie, w powiecie kowieńskim. M. Kulczyкowski, Pożerski Edward, w: PSB, t. XXVIII, Kraków 1984-1985, s. 316-317.

${ }^{4}$ PSB podaje, że do rot aresztanckich trafił w 1850 r. Tamże, s. 316. 
przez wstąpienie na tron Aleksandra II. Wziął udział w powstaniu 1863 roku, po którego upadku schronił się do Paryża i odtąd tu pozostaje prowadząc uczciwe, pracowite życie. Ożeniony z Polką ${ }^{5}$ ma syna i córkę. Pierwszy kończy swe studia medyczne, ostatnia daje lekcje i pomaga rodzicom i bratu. Całej rodziny charakter zacny". I właśnie ten zacny charakter cechował Edwarda Aleksandra Pożerskiego (1875-1964), który był osobistością nietuzinkową i bardzo barwną. Z zachowanych źródeł wyłania się obraz znakomitego uczonego, błyskotliwego publicysty, złotoustego mówcy, wyjątkowego smakosza, artysty malarza, członka licznych towarzystw naukowych, kulturalnych i społecznych, wieloletniego prezesa Towarzystwa Opieki nad Polskimi Zabytkami i Grobami Historycznymi we Francji. Był on strażnikiem historii i tradycji, ambasadorem polskiego dziedzictwa kulturalnego, romantykiem i rzeczywistym łącznikiem „między dawnymi i młodszymi laty”.

Edward Aleksander Pożerski (Édouard Alexandre de Pomiane) zawsze podkreślał, że rodzice nauczyli go kochać Polskę i posługiwać się bardzo dobrze językiem polskim, mimo że żył i pracował w środowisku francuskim. Ich losy i przekonania, zwłaszcza na sprawy narodowe, silnie na niego oddziaływały i wpłynęły na jego stosunek do kraju przodków, a także Francji. Równie silnie, jak atmosfera domowa, jego postawę i światopogląd ukształtowała nauka w szkole na Batignolles. Już jako dojrzały człowiek deklarował: „W gruncie, byłem bardzo szczęśliwy w życiu, z powodu mojego pochodzenia polskiego. Szczęśliwszy byłem i jestem szczęśliwszy od setek tysięcy obywateli francuskich, którzy mają tylko jedną jedyną ojczyznę do ukochania. Ja miałem i mam jeszcze dwie: Francję i Polskę. U Francuzów zawsze uchodzę za Polaka. Polacy mnie zawsze mają za Francuza. I jedni i drudzy mają rację"

Rodzina Pożerskich związana była z Wilnem, gdzie wpisana została do Ksiąg Szlacheckich Guberni Litewsko-Wileńskiej i od XVI wieku pieczętowała się herbem Pomian. Ślady tego rodowodu dostrzec można wśród zabytkowych grobów wileńskiego Cmentarza Bernardyńskiego na Zarzecu. Spoczywa tu dziadek od strony ojca - Feliks Pożerski (1803-1858), doktor medycyny, lekarz wojskowy w stopniu generała majora, członek i wiceprezes Wileńskiego Towarzystwa Lekarskiego ${ }^{8}$. A także inni przedstawiciele familii, np. pułkownik Władysław Pożerski i artylerzysta, generał brygady, odznaczony w 1924 r. Krzyżem Virtuti Militari, Olgierd Pożerski.

${ }^{5}$ Matka Olimpii Bielajew była Polką, ojciec zaś Rosjaninem. Sam Pożerski pisał, że jego matka była Rosjanką. L. Gocel, Ze wspomnień paryskich. Pożerscy, „Stolica” 1960, nr 7, s. 10.

${ }^{6}$ J. EkIELSKI, Fundacja Pelagji Russanowskiej, s. 131, 134.

${ }^{7}$ Dział Starej Książki Medycznej Główna Biblioteka Lekarska w Warszawie [dalej: DSKM GBL], Teki Stanisława Konopki, Edward Aleksander Pożerski, sygn. I/1051, k. nlb.

${ }^{8}$ J. BIELIŃSKI, Cesarskie Towarzystwo Lekarskie Wileńskie, jego prace i wydawnictwa (18051864), Warszawa 1890, s. 61; L. NARKowicz, My Polacy jesteśmy niezłomni ..., http:// www.magwil. 1t/archiwum/archiwum/2007/mag-3/mr-6.htm [dostęp: 23.08.2019]. 
Edward Pożerski (ojciec) w czasach gimnazjalnych przyjaźnił się z braćmi Franciszkiem i Aleksandrem Dalewskimi, przywódcami Związku Bratniego Młodzieży Litewskiej. Za przynależność do tej konspiracyjnej organizacji został wysłany w sołdaty, do rot aresztanckich w Orenburgu. W trakcie katorgi miał sposobność poznać się m.in. z Fiodorem Dostojewskim, który również przebywał karnie w przeduralskiej części Rosji - za aktywność w grupie młodych intelektualistów (tzw. Kołe Pietraszewskiego), krytykujących carski despotyzm i zacofanie kulturalno-gospodarcze ówczesnej Rosji. „Z czasem ci ludzie zbliżyli się do siebie i na tle wspólnych poglądów na sprawę wolności Polski i Rosji nawet zaprzyjaźnili się. Rozmowy ich odbywały się najczęściej przy herbacie z [...] samowara"”.

Po zakończeniu kary i powrocie do Wilna w 1862 r. aktywnie zaangażował się w przygotowania zrywu niepodległościowego. W trakcie powstania styczniowego był naczelnikiem wileńskiej żandarmerii, co w konsekwencji doprowadziło go do opuszczenia rodzinnego miasta $\mathrm{w}$ celu uniknięcia kolejnych represji. W towarzystwie przyjaciela, ilustratora i malarza Michała Elwiro Andriollego, również powstańca, dotarł do portu (prawdopodobnie w Rydze), skąd kapitan jakiegoś zagranicznego statku przeszmuglował ich na pokład. Na nieszczęście statek rozbił się u nadbrzeży Danii ${ }^{10}$, prowadzącej w tym czasie wojnę z koalicją Austrii i Prus (tzw. II wojną o Szlezwik). Po przymusowym postoju krajanie wyruszyli w dalszą drogę przez Anglię do Francji. Nad Sekwaną Pożerski przez pewien czas „,pędził nędzny żywot, aż rozpoznany przez znajomego wilnianina, uczestnika powstania i polecony przez niego starej emigracji, znalazł wreszcie skromny kawałek chleba"11. Wówczas jego los się odmienił, zaangażował się w działalność społeczną i charytatywną. Był członkiem Rady Przewodniczącej Towarzystwa Wzajemnej Pomocy w Paryżu oraz Delegacji Litewskiej, wpływowej organizacji, sprawującej kontrolę nad tzw. sumami litewskimi. Pełnił funkcję sekretarza Towarzystwa Dobroczynności Dam Polskich, był również skarbnikiem w Instytucji Czci i Chleba. Przez wiele lat pracował w Bibliotece Polskiej w Paryżu, był sekretarzem księcia Władysława Czartoryskiego. Jego postawa została dość szybko doceniona przez polską diasporę we Francji; w 1886 r. zasiadał - m.in. z Aleksandrem Chodźką i Józefem Bohdanem Zaleskim - w specjalnym komitecie powołanym w celu przeniesienia na cmentarz Montmorency ciał dwóch cenionych emigrantów, dramatopisarza Tomasza Augusta Olizarowskiego i powieściopisarza, publicysty Adama Rzążewskiego ${ }^{12}$.

9 L. Gocel, Ze wspomnień paryskich, s. 10.

${ }^{10}$ W Kopenhadze Andriolli zarabiał rysunkami na dalszą podróż. Podobnie zresztą było w Anglii, skąd razem z Pożerskim udali się do Paryża. Tamże.

11 Tamże.

12 M. Kulczykowski, Pożerski Edward, s. 317; Cmentarz polski w Montmorency, opracowali J. Skowronek oraz A. Bochenek, M. Cichowski, K. Filipow, Warszawa 1986, s. 199. 
We Francji poznał Marię Olimpię Bielajew (1840-1919), z którą ożenił się w 1869 r. ${ }^{13}$ Matka Olimpii była Polką, ojciec zaś Rosjaninem - lekarzem wojskowym pracującym w Warszawie. „Był uwielbiany przez młodzież polską. Gdy umarł, studenci polscy zanieśli [jego] trumnę na swych ramionach do cmentarza"14. Olimpia brała czynny udział w tajnych komitetach podczas powstania styczniowego ${ }^{15}$. Będąc córką Rosjanina - i ,siostrzenicą któregoś z satrapów generałów”16 miała ułatwiony dostęp do Cytadeli, dzięki czemu udało jej się „odkraść” kilku osadzonych tam Polaków. Otrzymując przepustkę do więzienia, w celu widzenia się ze skazańcem, któremu groziła kara śmierci, pod obszernych rozmiarów krynoliną przemycała kobiece stroje oraz przyrządy do golenia. Jej działalność została jednak zdekonspirowana, co zmusiło ją do ucieczki z kraju. Zaopatrzona stosownym glejtem Tymczasowego Rządu Narodowego, po różnych perypetiach bezpiecznie osiadła w Paryżu, gdzie dożyła sędziwych lat ${ }^{17}$. Podobnie jak mąż, włączyła się do pracy na rzecz polskich emigrantów. Pożerscy mieli troje dzieci ${ }^{18}-$ Witolda, Emilię i Edwarda. Zmarli w Paryżu. Edward pochowany został na cmentarzu Montparnasse (mowę pogrzebową wygłosił Wacław Gasztowtt), a jego nazwisko wyryte zostało na pomniku polskiego grobu zbiorowego w 17 alei $^{19}$. Olimpia przeżywszy prawie 80 lat, spoczęła w Montmorency (kwatera C, grób 610) ${ }^{20}$.

Edward Aleksander Pożerski urodził się 20 kwietnia 1875 r. w Paryżu. W jego domu posługiwano się językiem polskim ${ }^{21}$ i kultywowano polską tradycję, do tego stopnia, że jako mały chłopiec nie znał w ogóle języka francuskiego. Wspominał: „Sąsiedzi

13 DSKM GBL, Teki Stanisława Konopki.

${ }^{14}$ Archiwum Narodowe w Krakowie [dalej: ANK], Spuścizna Janiny Jasickiej, Korespondencja w sprawie uściślenia faktów z życia Olimpii Bielajew-Pożerskiej i Edwarda Pożerskiego, 29/1340/0/9/119, k. nlb.

15 M. BruchnalsKa, Ciche bohaterki. Udziat kobiet w powstaniu styczniowym, Miejsce Piastowe 1933, s. 182.

${ }^{16}$ L. Gocel, Ze wspomnień paryskich, s. 10.

17 „Czasami [...] opowiadała «fakta» swej podróży do Francji jako emigrantka, na przykład, że prosto pojechała do Towiańskiego do Szwajcarii, bo go uwielbiała. A to było 24 grudnia, ale uciekła od niego piechotą w nocy, gdy on jej powiedział, że nie uznawał «żadnych wigilijnych obiadów»!!! Tak moja matka uwielbiała polskie obyczaje" (ANK, Spuścizna Janiny Jasickiej).

${ }^{18} \mathrm{~W}$ biogramie w PSB jest informacja tylko o Edwardzie Aleksandrze. M. KULCZYKowsKi, Pożerski Edward, s. 317; DSKM GBL, Teki Stanisława Konopki.

${ }_{19}$ M. KulczyKowski, Pożerski Edward, s. 317.

${ }^{20}$ Pożerska z d. Bielajew Olimpia, http://www.tombeauxpolonais.eu/search/node/bielajew [dostęp: 23.08.2019]; Cmentarz polski w Montmorency, s. 198-199.

${ }^{21}$ „Jakie było wykształcenie mojej mamy? Nie wiem. Wiem, że mówiła po francusku jak Francuzka. Zawsze mówiła do mnie i mej siostry tylko po polsku” [podkr. - E.P.]. Zob. ANK, Spuścizna Janiny Jasickiej. 
nazywali mnie niedźwiadkiem, polskim niedźwiadkiem. W mieszkaniu rodziców był mój polski świat, mimo że znajdował się na wzgórzach Montmartre"22. Znajomość języka polskiego była dla niego zawsze bardzo ważna - ze swoją jedyną córką Wandą rozmawiał wyłącznie w języku ojczystym swych rodziców, przy całkowitej aprobacie żony, Francuski Charlotte Raymonde Watier ${ }^{23}$. Nienaganna polszczyzna była również jego znakiem rozpoznawczym. Odwiedzający go Polacy byli nią zachwyceni. Odnotował to m.in. Ludwik Gocel, historyk, znawca dziejów książki, bibliofil i kolekcjoner, członek Polskiego Towarzystwa Przyjaciół Książki w Paryżu, który urzeczony był jego mową, bardziej mickiewiczowską lub lelewelowską niż współczesną 24 . Podobnie spotkanie z nim zapamiętała profesor technologii żywienia Alina Dobrzańska, która z grupą uczonych z Polski zwiedzała Instytut Pasteura w 1957 r. ${ }^{25}$ Sam Pożerski tłumaczył to wychowaniem domowym, a także edukacją szkolną.

Rodzina Pożerskich żyła skromnie, w 1879 r. czteroletni Edward oddany został do ochronki ${ }^{26}$. Rok późnej trafił do szkoły Batignolles ${ }^{27}$, gdzie przez dziesięć lat otrzymywał ascetyczne utrzymanie, a przede wszystkim patriotyczną edukację, która odcisnęła piętno na późniejszym jego życiu. Mimo wielu ujemnych stron tej szkoły (jak np. surowa dyscyplina, srogie kary, nieustanne niedożywienie) pozostały mu o niej pozytywne wspomnienia, a nawet ckliwe. Dokładny opis metod dydaktycznych i wychowawczych, panującą atmosferę, wzajemne relacje między uczniami i nauczycielami zawarł w wydanej - z subwencji Association des Anciens Élèves de l'École Polonaise - w 1932 r. książeczce L'Ecole Polonaise ou l'esprit de 1830. W latach 60. XX wieku Stanisław Konopka ${ }^{28}$ chciał wydać tę pracę w thu-

22 M. Derbień, Ostatni z minionej epoki, „Dookoła Świata” 1960, nr 34, s. 10.

${ }^{23}$ Zdarzało się, że wracając do domu zwracał się do Wandy po francusku, wówczas jego żona natychmiast przypominała mu, że z córką wolno mu mówić tylko po polsku. Dodawała: „Co by twój ojciec na to powiedział, gdyby usłyszał, że rozmawiasz z córką po francusku”. L. Gocel, Ze wspomnień paryskich, s. 10. W PSB podana jest informacje, że żona była pracownikiem naukowym w Instytucie Pasteura. Natomiast w jednym z listów do S. Konopki pisał, że jest ona artystką, harfistką. Córka Wanda została lekarzem; wyszła za mąż za Francuza, z którym miała troje dzieci. Por. T. Ostrowska, Pożerski (Pomian-Pożerski) Edward Aleksander, pseud. De Pomian, w: PSB, t. XXVIII, Kraków 1984-1985, s. 319; DSKM GBL, Teki Stanisława Konopki.

${ }^{24}$ L. Gocel, Ze wspomnień paryskich, s. 10.

25 „Przywitał nas piękną mową polską, starszy pan o szlachetnym obliczu, o długich białych włosach i długi białych wąsach" (A. Dobrzańska, Profesor Edward Pomian-Pożerski (1875-1964), „Żywność, Żywienie, Prawo a Zdrowie” 9(2000), nr 1, s. 104).

${ }^{26}$ DSKM GBL, Teki Stanisława Konopki.

27 O historii szkoły i postaciach z nią związanych zob. I.H. PuGACEwICZ, Batignolles 1842-1874. Edukacja Wielkiej Emigracji, Warszawa 2017.

${ }^{28}$ Lekarz, historyk medycyny, bibliograf, bibliotekarz (twórca Głównej Biblioteki Lekarskiej), varsavianista. 
maczeniu na język polski, a także namawiał autora do przesłania spisanych po francusku innych jego wspomnień, których wydaniem zainteresowany był Państwowy Instytut Wydawniczy. W tej sprawie zwrócił się do niego jeden z redaktorów, który nawet przesłał propozycję tytułu („Obrazy i wspomnienia mego polskiego życia we Francji”) i projekt karty tytułowej. Pożerski sporządził maszynopisy swych rękopiśmiennych wspomnień i przesłał je do Warszawy, ale przesyłka nigdy nie dotarła ${ }^{29}$. Jako absolwent szkoły Wielkiej Emigracji, jeszcze po 70. latach znakomicie pamiętał jej przesłanie, które zdradził w rozmowie z Ludwikiem Goclem.

Zawsze nam mówiono, że dlatego się uczymy, aby dla Polski pracować i dla niej cierpieć, a gdy zajdzie potrzeba, to za nią walczyć. Przedstawiano nam polską ojczyznę w pięknych kolorach, jako kraj ludzi szlachetnych, walecznych i zawsze gotowych do walki o niepodległość. W tej Polsce widzianej przez pryzmat pedagogów batignolskich są nie tylko najzacniejsi na świecie ludzie, ale i najpiękniejsza przyroda. Profesor geografii Rubach tak nam mówił o Wieliczce ,jest tam sól, ale nie myślcie, że taka jak we Francji. To jest polska sól, bielutka i czysta, najlepsza na świecie ${ }^{30}$.

W starszych klasach Pożerski podobnie jak inni uczniowie, równolegle chodził do prestiżowego francuskiego Liceum Condorceta, do którego uczęszczała przede wszystkim zamożna nadsekwańska młodzież. „Jakże smętnie odbijały nasze skromne, nieraz łatane mundurki, wobec ich eleganckich ubrań. Ale nasi koledzy francuscy nie zadzierali nosa, przeciwnie, odnosili się do naszej biedy z jakąś subtelną dyskrecją, bo [...] wtedy emigracja polska cieszyła się ogólną sympatią, zarówno u starszych jak i młodych Francuzów"31.

Po zdaniu francuskiej matury w 1894 r., zapisał się na Wydział Nauk Przyrodniczych na Sorbonie. Dwa lata później uzyskał licence ès science naturelles, po czym na rok przerwał naukę, by odbyć służbę wojskową w piechocie. W 1897 r. został asystentem profesora Alberta Dastre' ${ }^{32}$, uznanego specjalisty w dziedzinie chemii fizjologicznej, ucznia Claude Bernarda ${ }^{33}$. W następnym roku ukazała się pierwsza współautorska praca Pożerskiego na temat enzymów trawiennych śliny, trzustki i jelita cienkiego u ssaków (Amylase el maltose de la salive, du pancréas et de l'intestine grêle des mammifères). W tym samym roku rozpoczął studia medyczne,

${ }^{29}$ DSKM GBL, Teki Stanisława Konopki.

${ }^{30}$ L. Gocel, Ze wspomnień paryskich, s. 10.

31 Tamże, s. 11.

32 Fizjolog, prowadził m.in. badania nad cukrzycą, enzymami i właściwościami krwi; w 1893 r. wprowadził pojęcie „fibrynolizy”, w celu zdefiniowania procesów samoistnego rozpuszczania się skrzepów krwi.

${ }^{33}$ Lekarz fizjolog, badał m.in. procesy trawienne, zasady reakcji odruchowych, krążenie tlenu w organizmie; jego laboratorium znajdowało się przy paryskim Ogrodzie Botanicznym. 
które ukończył doktoratem na temat enzymów trawiennych (De l'action favorisante du suc intestinal sur le pouvoir amylolitique du suc pancréatique de la salive) ${ }^{34}$.

W maju 1901 r. - dzięki poparciu profesora Dastre'a - rozpoczął pracę w pracowni fizjologii w Instytucie Pasteura, początkowo jako preparator, a od roku 1910 jako asystent ${ }^{35}$. Z placówką tą związany był przez całe życie ${ }^{36}$. Tu kontynuował badania nad enzymami trawiennymi i tu również uzyskał drugi doktorat, tym razem z nauk przyrodniczych (Contribution à l'étude physiologique de la papaïne, 1908) ${ }^{37}$. Przez przeszło 50 lat, w czasie świąt Bożego Narodzenia, przebrany w strój Père Noël rozdawał prezenty dzieciom pracowników Instytutu. Czynił to także będąc już na emeryturze ${ }^{38}$. Miał sposobność obserwacji zmiany pokoleniowej, dzieci, które otrzymały niegdyś po raz pierwszy prezent świąteczny od niego, po latach przyprowadzały własne na tę samą tradycyjną i rodzinną uroczystośćc ${ }^{39}$.

W pracy naukowej najbardziej interesowały go zagadnienia fizjologii trawienia, ale także immunologii. Badania w tym zakresie prowadził m.in. u boku Ilji Miecznikowa ${ }^{40}$, analizując mikrobiologię jelit u kręgowców, oraz Maurice Nicoleta, badając właściwości przeciwciał i zmiany składników soku trzustkowego zachodzące podczas procesu trawienia ${ }^{41}$.

Jednocześnie frapowały go efekty pracy Iwana Pawłowa - nagrodzonego w 1904 r. Noblem w dziedzinie medycyny (za badania nad fizjologią trawienia). Pojechał do niego do Petersburga, a współpraca ta - jak wspominał - zdecydowała o jego dalszej drodze naukowej. W wyniku prowadzonych badań doszli do wspólnego wniosku, „że czego się nie lubi, to się źle trawi”42. Przez kolejnych 20 lat Po-

${ }^{34}$ DSKM GBL, Teki Stanisława Konopki; T. Ostrowska, Pożerski (Pomian-Pożerski) Edward Aleksander, s. 317.

35 Jego ówczesne wynagrodzenie wynosiło 200 franków, co było „fortuną” dla młodego człowieka, który partycypował w utrzymywaniu rodziny. J. Brossollet, L'Institut Pasteur vu par un gastronome, http://www.biusante.parisdescartes.fr/sfhm/hsm/HSMx1989x023x001/HSMx 1989x023x001x0045.pdf [dostęp: 23.08.2019].

${ }^{36}$ Instytutowi Pasteura poświęcił odrębne wspomnienia, ogłoszone w formie powielanego maszynopisu (Souvenirs d'un demi-siecle a l'Institut Pasteur). Podał tu wiele, czasem zabawnych szczegółów związanych z pracownikami (np. w rozdziale La vie intime de l'Institut Pasteur), a czasem bardzo przejmujących, gdy opisywał ludzkie tragedie.

37 T. Ostrowska, Pożerski (Pomian-Pożerski) Edward Aleksander, s. 317.

${ }^{38}$ Po przejściu na emeryturę w 1940 r. bywał codziennie w swojej pracowni; został też kierownikiem Działu Popularyzacji Nauki Instytutu. Tamże, s. 318-319.

${ }^{39}$ K. Garbień, Tu zewsząd widać niebo, „Tygodnik Polski” nr 28(144), 10 VII 1960, s. 9.

${ }^{40}$ Rosyjski zoolog i mikrobiolog; od 1887 r. prowadził badania w Instytucie Pasteura, w 1904 r. został zastępcą dyrektora; laureat Nagrody Nobla z medycyny (1908).

${ }^{41}$ T. Ostrowska, Pożerski (Pomian-Pożerski) Edward Aleksander, s. 317.

${ }^{42}$ S. Konopka, Edward Pomian Pożerski, „Służba Zdrowia” nr 6, 9 II 1964, s. 2. 
żerski studiował „wszelkie przemiany pierwiastków pokarmowych w kuchni i otworzył [mu] się wówczas cudowny horyzont i naukowy i psychologiczny. Kuchnia jest wielką nauką i cudowną sztuką"43.

Warto zaznaczyć, że już w początkowej fazie kariery naukowej nurtowały go zagadnienia: co dzieje się z pokarmami w czasie ich przygotowywania, jak się one przekształcają, czym jest kuchnia i dlaczego każdy kraj ma swą odrębną sztukę przyrządzania potraw? Na rozwiązanie tych zagadnień poświęcił wiele lat pracy naukowej, zyskując duże uznanie oraz popularność.

Prowadząc badania głównie w zakresie fizjologii, higieny żywienia, bakteriologii oraz stworzonej przez siebie nowej gałęzi nauki - gastrotechniki, ogłaszał ich rezultaty dużo publikując i wygłaszając różne prelekcje. Pracował w Institut Scientifique d'Hygiène Alimentaire, Instytucie Pasteura czy w założonej przez siebie szkole gastronomicznej. Napisał blisko 200 prac naukowych, ponad 1000 artykułów o tematyce kulinarnej, przez 15 lat prowadził cotygodniowe audycje radiowe (w Radio-Paris) ${ }^{44}$. Popularyzując wiedzę gastronomiczną, z obawy przed wykluczeniem z grona naukowców, zdecydował się przybrać pseudonim, wykorzystując w tym celu herb familii. „Nikomu nie powiedziałem nic i zacząłem pisać całą moją kuchnię pod imieniem Edouard de Pomiane, a moją naukę (czyli prace naukowe) pod nazwiskiem Pożerski. Przez trzy lata nikt nie wiedział, że Pomiane to Pożerski i że Pożerski to Pomiane"45.

Badania i publikacje poświęcone kulinariom i sztuce jedzenia miały silne podłoże psychologiczne. Doświadczenia głodu ze szkolnych lat ${ }^{46}$ wpłynęły na jego stosunek do przygotowywania i spożywania posiłków. Już jako autorytet naukowy i koneser sztuki kulinarnej organizował np. comiesięczne obiady dla koleżanek i kolegów z Instytutu Pasteura oraz współpracujących z nimi studentów, na które sam przygotował menu. Często zapraszał odwiedzających Francję rodaków na własnoręcznie przygotowywane w domu posiłki. Na takich ucztach bywał u niego między innymi historyk sztuki i nauki, gnomonik i kolekcjoner Tadeusz Przypkowski, który wspominał kryształową karafkę Baccarata wypełnioną koniakiem z piwnic Polignac, którą gospodarz dostał od samej królowej Elżbiety. Przygotowując posiłek dla gościa z Jędrzejowa zużył prawie połowę trunku, podlewając nim trzy krokiety ze świeżymi truskawkami ${ }^{47}$. Z kolei wspomniany Ludwik Gocel, gdy za-

${ }^{43}$ Tamże.

${ }^{44}$ Jako zbiór felietonów zebrane zostały w dwa tomy pt. Radio Cuisine.

${ }^{45}$ S. Konopka, Edward Pomian Pożerski, s. 2.

${ }^{46}$ Wspominał o nauczycielu Ignacym Kozikowskim - ulubieńcu młodzieży, cieszącym się estymą - który zawsze oddawał uczniom swój deser oraz nosił po kieszeniach, wymieszane z tabaką, skórki od chleba, którymi częstował wygłodniałych wychowanków, pytając ,jak wam smakują te ciastka". L. Gocel, Ze wspomnień paryskich, s. 10.

${ }^{47}$ Karafka znajduje się w Muzeum Przypkowskich w Jędrzejowie. 
proszony został na „polski obiadek”, jako apéritif otrzymał „kieliszek autentycznej żubrówki i kawałek suchej kiełbasy" ${ }^{48}$. Następnie gospodarz przyrządzając danie główne, bieżąco informował gościa, że „do mięsa będzie kasza tatarczana, a sos zaprawi koniakiem"49.

Nie bez wpływu na sztukę kulinarną i podejście Pożerskiego do gastronomii pozostawała znajomość z innym wychowankiem szkoły na Batignolles - Henrykiem Babińskim. Łączyła ich nie tylko szczera przyjaźń, ale także podobne życiorysy. Babiński ukończył prestiżowe studia inżynierskie w École nationale supérieure des mines de Paris i był inżynierem górnictwa. Jednak jego dokonania - mimo sukcesów geologicznych (np. zbadanie i opisanie złóż złota w Gujanie, eksploracja pokładów węgla kamiennego w Chile, na terytorium Ziemi Ognistej czy Brazylii) - dziś raczej kojarzone są z gotowaniem i smacznym jedzeniem. Pod pseudonimem Ali-Baba wydał dzieło gastronomiczne z około pięcioma tysiącami przepisów, które przysporzyło mu dużą popularnośćc ${ }^{50}$.

Być może zainspirowany przez Ali-Babę, de Pomiane rozpoczął prasę pisarską, lecz nie od receptur kucharskich, ale od studium, które sam nazwał „filozofią jedzenia". Publikacja zatytułowana Bien manger pour bien vivr (Jeść dobrze, ażeby dobrze żyć), opatrzona przedmową Ali-Baby, doczekała się kilku wydań. Wydawnictwo - niespodziewanie dla samego autora - zdobyło uznanie świata nauki, zostało nawet nagrodzone przez Akademię Francuską, a także uzyskało aprobatę i doskonałe oceny kucharzy i restauratorów. Książki kucharskie Edouarda de Pomiane cieszyły się i cieszą nie tylko we Francji dużym powodzeniem ${ }^{51}$. Były one również tłumaczone na język angielski, czeski, duński, hiszpański, polski, niemiecki, holenderski czy szwedzki. Wykorzystywał on i inne drogi szerzenia wiadomości o zdrowym odżywianiu się i gotowaniu. Wspominał: „Jeździłem po całej Francji, Belgii, Hiszpanii, Szwajcarii, Holandii i Italii, by pokazywać osobiście, jak znając gastrotechnikę można przygotować publicznie sześć potraw w pięć kwadransów i to we fraku i w białym krawacie, czasem na scenach teatralnych wobec 2000 osób" 52.

Uważał, że odpowiednie i smaczne przyrządzanie potraw jest nie tylko bardzo istotne z punktu widzenia zdrowia i higieny, lecz również wiązał to zagadnienie ze szczęściem rodzinnym, co wyłożył w artykule ogłoszonym w 1925 r. w „Polskiej Gazecie Lekarskiej”. Zwracał tam uwagę na fakt, że: „człowiek szuka zmiany po-

${ }^{48}$ L. Gocel, Ze wspomnień paryskich, s. 10.

49 Tamże.

${ }^{50}$ Zob. J. PoIRIER, Les frères Babinski. Un couple franco-polonaise exemplaire, „Annales Centre Scientifique de l'Académie Polonaise des Sciences à Paris” 2012, vol. 14, s. 377-391.

${ }^{51}$ W 2010 r. w rankingu brytyjskiego tygodnika „The Observer” jedna z nich - La cuisine en dix minutes, ou, l'adaptation au rythme moderne znalazła się wśród 50 książek wszechczasów.

52 S. Konopka, Edward Pomian Pożerski, s. 2. 
żywienia, przyjemnej dla smaku i przez to samo pobudza się do apetytu, który jest kluczem jego dobrego odżywiania się. Większości uroczystych manifestacji życia towarzyszą tradycyjne uczty, a dom gdzie się dobrze je, jest zawsze pożądany jako oaza szczęścia"53. Postulował, aby gastrotechnikę wykładać w szkołach elementarnych, by ułatwić poznanie arkanów sztuki kulinarnej, jako ważnego komponentu cementującego relacje rodzinne ${ }^{54}$.

Zasługi uczonego, który zamiast dostojnej togi nosił kucharski fartuch, doceniono również w Polsce. Tadeusz Przypkowski stworzył odznaczenie i powołał Kapitułę Orderu Pomiana. Przyznawano go za wybitne zasługi na polu sztuki kulinarnej. Uhonorowano nim kilkunastu cudzoziemców, kilku Polaków oraz redakcję krakowskiego „Przekroju”. Kapitułę Orderu tworzyło 12 eminentnych smakoszy i degustatorów. Tytułem Wielkiego Mistrza obdarzono grafika, malarza i architekta Tadeusza Gronowskiego, funkcję Kanclerza powierzono pomysłodawcy. Order miał kształt kieliszka zawieszonego na wstędze z zapinką w kształcie miniaturowego kołduna. Kapitułę ustanowiono rok po śmierci Pożerskiego, a działała ona do $1976 \mathrm{r}^{55}$

Pożerski był żywą kroniką zdarzeń związanych z aktywnością organizacji polskich we Francji i brał czynny udział w wielu ich działaniach. Jego rola w spójni dwóch narodów była znacząca i nie do przecenienia. Zaraz po wyjściu ze szkoły na Batignolles zaangażował się w działalność organizacji skupiającej jej absolwentów. Deklarował, że wychowankowie tak bardzo byli związani ze szkołą, że po opuszczeniu jej murów - poczynając od 1852 r. - w każdy pierwszy wtorek miesiąca spotykali się w małej kawiarence, aby „pogadać o naszej Polsce, naszej psychologii francusko-polskiej" 56 . Jako prezes Towarzystwa Byłych Uczniów Szkoły Batignolskiej raz do roku organizował spotkanie we własnym domu dla swoich szkolnych kolegów (w 1959 r. było ich już tylko 20) ) $^{57}$. Prócz tego odwiedzał młodzież współcześnie uczącą się na Lamandé, gdzie „z niezwykłą swadą opowiadał przepiękną francuszczyzną o tym, czym niegdyś była szkoła batignolska. W ustach mówcy słowa drgały niezwykłym wzruszeniem, które udzieliło się wszystkim obecnym" 58 .

53 E. Pożerski (Edouard de Pomian), Nauka o gotowaniu, „Polska Gazeta Lekarska” 1925, nr 21, s. 489.

${ }^{54}$ Tamże.

55 I.H. Pugacewicz, Edward Pomian Pożerski - promotor francuskiej gastronomii i polskich tradycji nad Sekwana, w: Wkład Polaków w kulturę Europy i Świata. Skromni ludzie - wielkie dokonania, t. II, red. A. Kamler i I.H. Pugacewicz, Warszawa 2018, s. 97-115.

${ }^{56}$ DSKM GBL, Teki Stanisława Konopki.

57 Tamże.

${ }^{58}$ M. Derbień, Ostatni z minionej epoki, s. 10. 
Towarzystwo od 1875 r. wydawało „Bulletin Polonais Littéraire, Scientifique et Artistique" - miesięcznik redagowany po francusku, w którym skrupulatnie odnotowywano wszystkie istotne sprawy i wydarzenia dotyczące Polaków, uprzystępniając je Francuzom ${ }^{59}$. W piśmie był stały, w miarę bieżący, przegląd osiągnięć polskiej nauki, literatury i sztuki. Ponadto drukowano tłumaczenia dzieł literatury romantycznej i współczesnej, wspomnienia emigrantów, jak również nekrologi polskiego wychodźstwa, które dla biografistyki stanowią nierzadko jedyne źródło. Na przykład w 1880 r. numer 11. poświęcony został Józefowi Ignacemu Kraszewskiemu i literaturze polskiej oraz polskim artystom działającym w nadsekwańskich salonach. W kolejnym zaś znalazł się przekład Wacława Gasztowtta koncertu Jankiela. Pożerski wydawał to pismo przez 15 lat, w latach $1908-1922^{60}$, aczkolwiek w jednym z listów wspominał, że związany z nim był już od $1894 \mathrm{r}^{61}$

W pierwszych dniach lutego 1922 r., jako ostatni redaktor naczelny „Biuletynu Polskiego" "62, wystosował do czytelników list pożegnalny następującej treści:

Ponad 48 lat „Biuletyn Polski” stał na straży informacji i oświecania francuskiej opinii publicznej na temat przeszłości i teraźniejszej sytuacji Polski. Jego cel i dążenia zawsze pozostawały niezmienne. Były to cel i dążenia polskiej emigracji. Jak nasi ojcowie, tak i my pragnęliśmy Polski wolnej i niezależnej. Dzisiaj cel ów został osiągnięty. „Biuletyn Polski” już się nie ukaże. Pozostaje nam pochylić się przed wspaniałym oddaniem naszych dawnych kolegów i podziękować współpracownikom, abonentom i czytelnikom za nieustanne wspieranie nas w wysiłkach. To oni przyczynili się również do zmartwychwstania Polski. Niech żyje Polska! ${ }^{63}$

We własnej biblioteczce posiadał idealny komplet periodyku; kilkanaście opasłych tomów, przechowywanych w sąsiedztwie dzieł Juliusza Słowackiego, którego bardzo cenił. Tym bardziej poczytywał za wielki zaszczyt fakt, iż był honorowym przedstawicielem emigracji, który towarzyszył doczesnym szczątkom Słowackiego w drodze z Paryża na Wawel. To doniosłe wydarzenie związane było z jego działalnością w Komitecie Opieki nad Grobami Polskimi we Francji ${ }^{64}$, który

59 Biblioteka Polska w Paryżu [dalej: BPP], Depozyt 10: E. Pozerski, Le Buletin Polonais, maszynopis [po 5 II 1923], s. 2-3.

${ }^{60}$ L. Gocel, Ze wspomnień paryskich, s. 11.

${ }^{61}$ DSKM GBL, Teki Stanisława Konopki.

${ }^{62}$ Szerzej na temat czasopisma zob. I.H. Pugacewicz, Wkład batignolczyków i Biuletynu Polskiego w umocnienie polskiej tożsamości, kultury i polityki na Zachodzie, „Studia Medioznawcze” 20(2019), nr 3, s. 265-279.

${ }_{63}$ Thumaczenie z języka francuskiego I.H. Pugacewicz (Eduard Pozerski, Le Buletin Polonais, s. 5).

${ }^{64}$ Inicjatywa Karola Sienkiewicza, który po śmierci Juliana Ursyna Niemcewicza powołał Komisję Grobów Polskich. Archiwum Towarzystwa Opieki nad Polskimi Grobami Historycznymi we 
m.in. z jego inicjatywy w 1949 r. zmienił nazwę na Towarzystwo Opieki nad Grobami Zasłużonych Ojczyźnie Polaków we Francji ${ }^{65}$.

Pochówek Szat Anioła odbył się dwa dni po jego śmierci, 5 kwietnia 1849 r., na cmentarzu Montmartre. Przygotowany był pośpiesznie, bardzo skromnie, nie miał oprawy godnej ceremonii narodowej ani tym bardziej manifestacji patriotyzmu ${ }^{66}$. Ksiądz Zygmunt Szczęsny Feliński, utrzymujący serdeczne i przyjacielskie kontakty ze Słowackim, w liście do Leopolda Mèyeta pisał:

Suma pozostała po śmierci [...] była bardzo szczupła, a że ani ja, ani wykonawcy testamentu nie byliśmy w stanie coś do niej dodać, trzeba więc było poprzestać na 9 klasie pogrzebu, żeby wystarczyło przynajmniej na kupienie grobu na wieczność, co kosztowało 500 fr. We 24 godziny po skonstatowaniu zgonu, ciało niebalsamowane winno być pogrzebane, nie starczyło więc czasu na drukowanie żałobnych obwieszczeń, pogrzeb więc odbył się tak skromnie, że zaledwie kilkanaście osób, i to nie głośnych nazwisk towarzyszyło konduktowi z mieszkania poety na cmentarz. [Również] mowy nie było żadnej [...] bo nie było ani komu, ani do kogo przemawiać6 ${ }^{67}$.

W 1900 r. na łamach ,Tygodnika Ilustrowanego” Mèyet opublikował rachunek z pogrzebu Juliusza Słowackiego, który odnalazł w archiwach szkoły batignolskiej ${ }^{68}$.

Przygotowania do sprowadzenia prochów Juliusza Słowackiego „na Ojczyzny łono" rozpoczęły się na długo jeszcze przed odzyskaniem niepodległości. Już w 1885 r. krakowscy studenci podjęli w tym celu pewne działania, nawet zorganizowali zbiórkę pieniędzy. W kolejnych latach w sprawę angażowali się przed-

Francji [1805] 1930-1995. Inwentarz tymczasowy, oprac. A. Biernat, I. Dacka-Górzyńska, S. Górzyński, J. Pezda, Edition La Rama 2017, s. 8; BPP, Depozyt 1 [Sprawy organizacyjne Towarzystwa, korespondencja, sprawy kasowe], k. nlb.

${ }^{65} 29$ listopada 1949 r. odbyło się pierwsze po II wojnie światowej zebranie wznawiające działalność Komitetu Opieki nad Grobami Polskimi we Francji, podczas którego omówiono sprawy związane z odtworzeniem dawnych napisów na grobie członków Rządu Narodowego z 1830-1831 r. przy Avenue des Polonia na cmentarzu Montmartre, korektą daty urodzenia na mogile Norwida na Montmorency. Z wystosowanych 24 zaproszeń do członków Towarzystwa w spotkaniu uczestniczyły tylko cztery osoby. BPP, Depozyt 40 [Protokoły posiedzeń Towarzystwa], k. nlb.

${ }^{66}$ Norwid wspominał: „Ja - na pogrzebie tym żeńskich istot widziałem dwie - jedna z tych rzewnymi łzami zalana była, co mi wspomnieniem zostało bardzo pocieszającym na wiele dni potem, kiedy liczne podówczas społeczeństwo polskie w Paryżu bawiące się odwiedzałem był - bo wiele było (jak zawsze świetnych i niepospolitych) Polek podówczas w Paryżu” (G.P. BĄBIAK, Funeralia narodowe. Pogrzeby patriotyczne Polaków w czasie niewoli, Warszawa 2016, s. 411).

${ }^{67}$ L. MÈYET, Pogrzeb Stowackiego, „Tygodnik Ilustrowany” 1896, nr 44, s. 862.

${ }^{68}$ L. MÈYET, Jeszcze słów kilka o pogrzebie Juliusza Stowackiego, „Tygodnik Ilustrowany” 1900 , nr 44, s. 871. 
stawiciele środowiska kulturalno-naukowego w Paryżu, Krakowie i Warszawie ${ }^{69}$. Ziściło się to dopiero w 1927 r., gdy premierem był marszałek Józef Piłsudski, prywatnie wielki miłośnik twórczości wieszcza. Wówczas rząd podjął uchwałę o sprowadzeniu do kraju szczątków poety. W kwietniu premier napisał list do arcybiskupa Adama Sapiehy z prośbą o zajęcie stanowiska w sprawie wawelskiego pogrzebu. Metropolita wyraził zgodę, podkreślając, że czyni to w drodze wyjątku. Obawiał się, aby swoją decyzją nie otworzyć drogi innym pochówkom w kryptach, gdzie nie było już wystarczająco miejsca.

14 czerwca 1927 r. obyła sie ekshumacja na Montmartre, po czym trumna z cmentarza przewieziona została do polskiej ambasady na karawanie, wcześniej wykorzystanym do transportu ciała Napoleona Eugeniusza Bonapartego. Nie był to karawan żałobny, lecz błękitno-srebrny, bowiem według Pożerskiego: „Polska odrodzona nie była w żałobie, lecz czciła geniusza Słowackiego"70. Znad Sekwany w ostatnią podróż wyruszył na polskim okręcie „Wilia”. Później na statku „Mickiewicz" płynął z Gdańska do Warszawy. Znad nadwiślańskiej przystani kondukt przeszedł na plac Zamkowy, gdzie odbyło się uroczyste powitanie prochów poety. Następnie trumnę wystawiono w katedrze św. Jana ${ }^{71}$. Nazajutrz, w samo południe, przy dźwiękach Marsza żałobnego Chopina, specjalnie przygotowany pociąg wyruszył do Krakowa ${ }^{72}$.

W dniu właściwej uroczystości pogrzebowej - 28 czerwca - Kraków żegnał wieszcza w strugach deszczu. Rankiem w Barbakanie biskup Stanisław Rospond odprawił Mszę świętą. Po nabożeństwie w asyście tłumnie zgromadzonych żałobników trumnę z „królewskimi”" ${ }^{\prime 3}$ honorami odprowadzono do wawelskich krypt. Udział w tym wydarzeniu był dla Pożerskiego bardzo ważny i na zawsze zapisał się w jego pamięci. W jednej z audycji radiowych we francuskim radio (wyemitowanej 15 II 1955) wracał do tych wydarzeń opowiadając, że marszałek Piłsudzki przywitał Słowackiego w imieniu Polski, on zaś pożegnał go w imieniu emigracji. Mówił: „Widziałem, jakby we śnie, wszystkich emigrantów wracających do Polski. Idą oni, a liczba ich jest tak wielką, że na ciasnym niebie tworzą drugą mleczną drogę,

${ }^{69}$ A. Górski, Gdzie złożyć zwłoki Juliusza Stowackiego, „Tygodnik Ilustrowany” 1907, nr 51, s. 1034; J. Wiśniowski, Pochód na Wawel. Pamiątka z pogrzebu Juljusza Stowackiego (14-18 czerwca 1927 r.), Kraków 1927.

${ }^{70}$ BPP, Depozyt 40 [E. Pomian-Pożerski, O grobach polskich na ziemi francuskiej, 15 II 1955], k. nlb.

71 J. Wiśniowski, Pochód na Wawel, s. 50-60.

72 Szczegółowy opis uroczystości zob. tamże, s. 73-122.

${ }^{73}$ Z przemówienia marszałka Piłsudskiego: „W imieniu Rządu Rzeczypospolitej polecam Panom odnieść trumnę Juliusza Słowackiego do krypty królewskiej, by królom był równy" (tamże, s. 113). 
błyszczącą ideałem. Dochodzą do ziemi polskiej, zatrzymują się. Zaraz uklękną i ucałują tę świętą ziemię"74.

Mimo iż stronił od bieżącej polityki, to sprawy polskie zawsze pozostawały w centrum jego zainteresowań. Był mocno zaangażowany w działalność Towarzystwa Opieki nad Grobami Zasłużonych Ojczyźnie Polaków we Francji, którego był prezesem, włączał się również w aktywność Polskiego Towarzystwa Przyjaciół Książki w Paryżu, a także w inne emigracyjne inicjatywy mające przybliżyć Francuzom historię i kulturę Polski. Na pierwszym powojennym zebraniu Towarzystwa Opieki nad Grobami wyznaczył jego podstawowe zadania: „Towarzystwo nasze ma na celu ten święty obowiązek: unieśmiertelniać bohaterów naszej historii polskiej, zostawiając po nas, na przyszłość, ich nazwiska wyryte w kamieniu. Nasz cel, nasz obowiązek, są święte" 75 . Z jego inicjatywy i przy wsparciu finansowym udało się ocalić i odrestaurować wiele polskich grobów, jak np. nagrobek króla Jana Kazimierza w kościele St. Germen des Prése, kwatery na cmentarzu w Montmorency (m.in. Juliana Ursyna Niemcewicza i generała Karola Kniaziewicza, Władysława Zamoyskiego) czy na Montmartre zbiorową mogiłę członków Rządu Narodowego $1830-1831^{76}$.

To on przez wiele lat żegnał odchodzących rodaków, rzucając na ich trumny grudki polskiej ziemi, którą zabrał ze sobą do Francji, spod sosen w parku w Żelazowej Woli. Miejsce urodzenia Chopina splatało się w jego pamięci z postacią siostrzeńca, sieroty Jakuba Jędrzejewicza, wychowanego w domu Pożerskich, który zginął w czasie I wojny światowej, służąc w szeregach armii francuskiej. W pośmiertnym wspomnieniu napisał o nim: „Jakub oddał Francji krew, którą od niej otrzymał Fryderyk" "77.

Jego stosunek do funerali narodowych został ukształtowany w rodzinnym domu, ale przede wszystkim w batignolskiej szkole, gdzie w rocznicę powstania listopadowego:

$\mathrm{Z}$ rana była msza święta w polskim kościele Assomption ${ }^{78}$. W południe na śniadanie dzieciaki $[\ldots]$ dostawały trochę konfitur. Rok w rok czekaliśmy z niecierpliwością na te konfitury i na tę uroczystość. Nasz Dyrektor, Stanisław Malinowski, emigrant

${ }^{74}$ BPP, Depozyt 40 [Groby polskie na ziemi francuskiej, przed II 1955], k. nlb.

75 BPP, Depozyt 40 [Przemówienie Edwarda Pożerskiego, 29 XI 1949], k. nlb.

${ }^{76}$ Szerzej na temat opieki nad polskimi grobami we Francji zob. D. Pietrzkiewicz, „Życie zmartych złożone jest w pamięci żywych”. Działalność Edwarda Aleksandra Pożerskiego na rzecz Towarzystwa Opieki nad Polskimi Zabytkami i Grobami Historycznymi we Francji, w: Dziedzictwo narodowe poza granicami Polski: Francja, red. D. Kuźmina, Warszawa 2019, s. 35-61.

${ }^{77}$ K. Garbień, Tu zewsząd widać niebo, s. 9.

${ }^{78}$ W 1844 r. arcybiskup Paryża przekazał Kościół Najświętszej Maryi Panny Wniebowziętej Polskiej Misji Katolickiej we Francji i od tego czasu jest on główną świątynią polskiej emigracji. 
z 1830-go roku, nakładał swój czarny tużurek. Uczniowie zdobili cały gmach szkoły w banderole z papierów różnobarwnych. Polski sztandar był wywieszany nad drzwiami naszej szkoły. Wieczorem w sali Towarzystwa Geograficznego przy [bulwarze] Saint-Germain zebranie (na pół literackie i historyczne, na pół artystyczne) czciło dzieje powstania. Emigranci z 1830 roku siedzieli w pierwszych rzędach foteli. Dzieci patrzyły na nich jak na jakichś świętych, na jakichś bohaterów. Na koniec posiedzenia cała sala śpiewała hymn Legionów Polskich: Jeszcze Polska nie zginęla ${ }^{79}$.

Paryskie mieszkanie de Pomiane’a miało niemalże muzealny charakter. Zgromadził w nim pokaźną ilość pamiątek rodzinnych i narodowych, a także dzieł sztuki reprezentujących twórczość polskich malarzy, którzy w różnych okresach tworzyli we Francji. W eksponowanym miejscu - pod portretem jego ojca - stał przenośny samowar, z którego ten pił herbatę wraz z Dostojewskim. Odwiedzający dom mieli wrażenie, że przenieśli się w epokę mickiewiczowskich Sopliców, Horeszków i Wojskich. Michał Andriolli, znakomity ilustrator Pana Tadeusza, rysował swoje postacie na wzór starego powstańca i sybiraka, do którego jego syn z wiekiem stawał się coraz bardziej podobny ${ }^{80}$.

Pożerski przyjaźnił się nie tylko z ludźmi nauki, ale również z artystami; gościli u niego przedstawiciele francuskiej i polskiej bohemy. Sam także malował obrazy, część z nich została sprzedana, część rozdana wśród znajomych i przyjaciół, a część pozostała w jego mieszkaniu. Lekcji rysunku udzielał mu sam Jan Styka, urodzony we Lwowie malarz, ilustrator książkowy, współtwórca Panoramy Racławickiej. Pod koniec lat 50. namówiony przez znajomych artystów de Pomiane zorganizował nawet wystawę własnych prac, którą anonsował „du goulache au gouache"81.

W ojczyźnie swych rodziców bywał bardzo rzadko. Po raz pierwszy w 1889 r., gdy został zaproszony do polskiego dworku przez znajomą Francuzkę, żonę Polaka. Po raz drugi przyjechał w 1911 r. jako uczestnik XI Zjazdu Lekarzy i Przyrodników w Krakowie. Ponownie przybył tu wraz z prochami Słowackiego w 1927 r., a ostatni raz w 1960 r., gdy przyjechał na zaproszenie Państwowego Zakładu Higieny w Warszawie ${ }^{82}$.

Edward Aleksander Pożerski dożył 89 lat. Zginął w wypadku samochodowym 26 stycznia 1964 r. W żałobnej mowie jego młodszy kolega z batignolskiej szkoły Karol Brzezicki żegnał go:

79 BPP, Depozyt 40 [Przemówienie Edwarda Pożerskiego, 29 XI 1949], k. nlb.

${ }^{80}$ M. Derbień, Ostatni z minionej epoki, s. 10.

81 A. DobrZaŃSKa, Profesor Edward Pomian-Pożerski, s. 103; L. Gocel, Ze wspomnień paryskich, s. 13.

82 S. Konopka, Edward Pomian Pożerski, s. 2. Wizytę odnotował również „Tygodnik Polski” nr 28(144), 10 VII 1960, s. 8 oraz „Ekspress Wieczorny” nr 139, 9 VI 1960, s. 2. 
Mieszkałeś we Francji i jako taki na innym planie oddałeś się całkowicie pracy na rzecz drugiej ojczyzny i my chlubiliśmy się wspaniałymi wynikami niestrudzonej działalności całego Twojego życia, uwieńczonej światową sławą. Można było powiedzieć o Tobie to, co mówiono o Twoim Nauczycielu - Gasztowcie, obok którego spoczniesz: «Najistotniejszy Polak wśród Francuzów, najistotniejszy Francuz wśród Polaków». Polakiem byłeś Twoją piękną postawą, spojrzeniem jasnym i wesołym, sumiastym wąsem. [...] Twoją całkowitą pogardą dla polityki. Nie byłeś ani krzty homo politicus i tę pogardę dla gry politycznej, która sprowadziła tyle nieszczęść na Polskę, odziedziczyłeś po swoich przodkach. [...] Byłeś Francuzem przez strukturę umysłową, przez styl jasny i wytworny, przez techniczne wykształcenie przepojone tą jasnością i uczciwością jakie cechuje Szkołę Pasteura ${ }^{83}$.

\section{BIBLIOGRAFIA}

\section{Źródla archiwalne}

Archiwum Narodowe w Krakowie

Spuścizna Janiny Jasickiej, Korespondencja w sprawie uściślenia faktów z życia Olimpii Bielajew-Pożerskiej i Edwarda Pożerskiego, 29/1340/0/9/119, k. nlb.

Dział Starej Książki Medycznej Główna Biblioteka Lekarska w Warszawie

Teki Stanisława Konopki, Edward Aleksander Pożerski, sygn. I/1051, k. nlb.

Polska Biblioteka w Paryżu

Materiały Towarzystwa Opieki nad Polskimi Zabytkami i Grobami Historycznymi we Francji:

Depozyt 1: Sprawy organizacyjne Towarzystwa, korespondencja, sprawy kasowe, 1951-1976

Depozyt 10: Materiały po Janie Szymańskim, 1958-1962

Depozyt 13: Biogramy zmarłych na emigracji członków Towarzystwa, cz. 1, 19831992

Depozyt 40: Protokoły posiedzeń Towarzystwa, 1949-1956

\section{Opracowania}

Archiwum Towarzystwa Opieki nad Polskimi Grobami Historycznymi we Francji [1805] 1930-1995. Inwentarz tymczasowy, oprac. A. Biernat, I. Dacka-Górzyńska, S. Górzyński, J. Pezda, Bellerive-sur-Allier: Edition La Rama 2017.

${ }^{83}$ BPP, Depozyt 13 Biogramy zmarłych na emigracji członków Towarzystwa, k. nlb. W jego mogile znajduje się garstka polskiej ziemi, którą przechowywał w swoim paryskim mieszkaniu jako cenną relikwię. 
BĄBIAK G.P., Funeralia narodowe. Pogrzeby patriotyczne Polaków w czasie niewoli, Warszawa: Instytut Historii PAN 2016.

BIELIŃSKI J., Cesarskie Towarzystwo Lekarskie Wileńskie, jego prace i wydawnictwa (1805-1864), Warszawa: druk K. Kowalewskiego 1890.

Brossollet J., L'Institut Pasteur vu par un gastronome, http://www.biusante.parisdescartes.fr/sfhm/hsm/HSMx1989x023x001/HSMx1989x023x001x0045.pdf [dostęp: 23.08. 2019].

BRUChNaLSKa M., Ciche bohaterki. Udział kobiet w powstaniu styczniowym, Miejsce Piastowe: Wydawnictwo Towarzystwa św. Michała Archanioła 1933.

Cmentarz polski w Montmorency, opracowali J. Skowronek, A. Bochenek, M. Cichowski, K. Filipow, Warszawa: Państwowy Instytut Wydawniczy 1986.

DerbieŃ M., Ostatni z minionej epoki, „Dookoła Świata” 1960, nr 34, s. 10.

DobrZaŃsKa A., Profesor Edward Pomian-Pożerski (1875-1964), „Żywność, Żywienie, Prawo a Zdrowie" 9 (2000), nr 1, s. 102-104.

EKIELSKI J., Fundacja Pelagji Russanowskiej. Urywek z pamiętnika Józefa Ekielskiego długoletniego referenta wydziału krajowego b. Królestwa Galicji i Lodomerji, Miejsce Piastowe: Wydawnictwo Towarzystwa św. Michała Archanioła 1931.

Garbień K., Tu zewsząd widać niebo, „Tygodnik Polski” nr 28 (144), 10 VII 1960, s. 9.

Gocel L., Ze wspomnień paryskich. Pożersc, „Stolica” 1960, nr 7, s. 10-11, 13.

GóRSKI A., Gdzie złożyć zwłoki Juliusza Słowackiego, „Tygodnik Ilustrowany” 1907, nr 51, s. 1034.

Konopka S., Edward Pomian Pożerski, „Służba Zdrowia” nr 6, 9 II 1964, s. 2.

KulczYKowski M., Pożerski Edward, w: PSB, t. XXVIII, Kraków 1984-1985, s. 316-317.

MÈYET L., Jeszcze słów kilka o pogrzebie Juliusza Słowackiego, „Tygodnik Ilustrowany” 1900, nr 44, s. 870-871.

MÈYET L., Pogrzeb Słowackiego, „Tygodnik Ilustrowany” 1896, nr 44, s. 862-863.

NARKowicz L., My Polacy jesteśmy niezłomni..., http://www.magwil.lt/archiwum/archiwum $/ 2007 / \mathrm{mag}-3 / \mathrm{mr}-6 . \mathrm{htm}$ [dostęp: 23.08.2019].

Nieznane listy dotyczące Fundacji Pelagii Russanowskiej z Biblioteki Polskiej w Paryżu, oprac. P. Bilińśki, T. Skrzyński, „Wrocławskie Studia Wschodnie” 13 (2009), s. 143-153.

Ostrowska T., Pożerski (Pomian-Pożerski) Edward Aleksander, pseud. De Pomian, w: PSB, t. XXVIII, Kraków 1984-1985, s. 317-319.

PerkowsKa U., Russanowska Pelagia, w: Polski Słownik Biograficzny, t. XXXIII/1, z. 136, Wrocław 1991, s. 145-146.

PietrZKiewicz D., „Życie zmarłych złożone jest w pamięci żywych”. Działalność Edwarda Aleksandra Pożerskiego na rzecz Towarzystwa Opieki nad Polskimi Zabytkami i Grobami Historycznymi we Francji, w: Dziedzictwo narodowe poza granicami Polski: Francja, red. D. Kuźmina, Warszawa: SBP 2019, s. 35-61.

PoIrIER J., Les frères Babinski. Un couple franco-polonaise exemplaire, „Annales - Centre Scientifique de l'Académie Polonaise des Sciences à Paris" 2012, vol. 14, s. 377-391.

PożERSKI (Edouard de Pomian), Nauka o gotowaniu, „Polska Gazeta Lekarska” 1925, nr 21, s. 489. 
PugacewiCz I.H., Batignolles 1842-1874. Edukacja Wielkiej Emigracji, Warszawa: Oficyna Wydawnicza ASPRA-JR 2017.

Pugacewicz I.H., Edward Pomian Pożerski - promotor francuskiej gastronomii i polskich tradycji nad Sekwaną, w: Wkład Polaków w kulturę Europy i Świata. Skromni ludzie - wielkie dokonania, t. II, red. A. Kamler i I.H. Pugacewicz, Warszawa: Grupa Cogito 2018, s. 97-115.

Pugacewicz I.H., Wkład batignolczyków i Biuletynu Polskiego w umocnienie polskiej tożsamości, kultury i polityki na Zachodzie, „Studia Medioznawcze” 20 (2019), nr 3, s. $265-279$.

SoKUlSki J., Ekielski Józef, w: Polski Słownik Biograficzny, t. VI, Kraków 1948, s. 220-221. WiŚNIOWSKI J., Pochód na Wawel. Pamiątka z pogrzebu Juljusza Słowackiego (14-18 czerwca 1927 r.), Kraków: Staraniem „Komitetu Sprowadzenia zwłok Jul. Słowackiego do kraju" 1927.

\section{FRANCUSKO-POLSKIE ŻYCIE EDWARDA ALEKSANDRA POŻERSKIEGO}

Streszczenie

Celem artykułu jest przedstawienie sylwetki Edwarda Aleksandra Pożerskiego, który był lekarzem, wieloletnim pracownikiem Instytutu Pasteura, autorem prac naukowych na temat zasad odżywiania się i przygotowywania posiłków oraz bardzo popularnych książek kucharskich. Należał on do licznych towarzystw naukowych, kulturalnych i społecznych. Był prezesem Towarzystwa Opieki nad Polskimi Zabytkami i Grobami Historycznymi we Francji oraz przedstawicielem nadsekwańskiej emigracji, gdy przewożono prochy Juliusza Słowackiego z Paryża na Wawel. Był ambasadorem polskiej historii i dziedzictwa kulturalnego. Podstawę tekstu stanowią materiały archiwalne z kolekcji Biblioteki Polskiej w Paryżu (Archiwum Towarzystwa Opieki nad Polskimi Zabytkami i Grobami Historycznymi we Francji), Zbiorów Specjalnych Głównej Biblioteki Lekarskiej (tzw. Teki Stanisława Konopki), Archiwum Narodowego w Krakowie (fragmenty spuścizny Janiny Jasickiej) oraz literatura przedmiotu.

Słowa kluczowe: Edward Aleksander Pożerski; Polacy we Francji; Towarzystwo Opieki nad Polskimi Zabytkami i Grobami Historycznymi we Francji; Instytut Pasteura 


\title{
THE FRENCH AND POLISH LIFE \\ OF EDWARD ALEKSANDER POŻERSKI
}

\begin{abstract}
Sum mary
The aim of the article is to present the figure of Edward Aleksander Pożerski who was a doctor, a long-time employee of the Pasteur Institute, the author of scientific papers on the principles of eating and preparing meals as well as very popular cookbooks. He belonged to numerous scientific, cultural and social associations. He was the president of the Society for the Care of Polish Historical Monuments and Tombs in France and a representative of the French emigration when Juliusz Słowacki's ashes were moved from Paris to the Wawel Castle in Kraków. He was an ambassador of Polish history and cultural heritage. The article is based on archival materials from the collection of the Polish Library in Paris (Archive of the Society for the Care of Polish Historical Monuments and Tombs in France), the Special Collection of the Main Medical Library in Warsaw (the so-called Stanisław Konopka Files), the National Archive in Kraków (fragments of Janina Jasicka's legacy) and the literature on the subject.
\end{abstract}

Keywords: Edward Aleksander Pożerski; Poles in France; Society for the Care of Polish Historical Monuments and Tombs in France; Pasteur Institute 